THE EVIDENCE ROOM 
This page intentionally left blank 


\title{
THE EVIDENCE ROOM
}

\author{
Anne Bordeleau \\ Sascha Hastings \\ Donald McKay \\ Robert Jan van Pelt
}

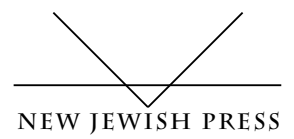


Copyright (C) 2016 Robert Jan van Pelt and others

All rights reserved including the right to reproduce

this book or portions thereof in any form whatsoever.

New Jewish Press

University of Toronto Press

Toronto Buffalo London

utorontopress.com

Editor: Sascha Hastings

Designer: Louis-Charles Lasnier

Production: Jolin Masson

Library and Archives Canada Cataloguing in Publication

The evidence room / Anne Bordeleau, Sascha Hastings,

Donald McKay, Robert Jan van Pelt.

Includes bibliographical references.

ISBN 978-1-988326-00-9 (hardback)

1. Auschwitz (Concentration camp)-Buildings. 2. Concentration camp buildingsPoland-Design and construction. 3. Holocaust, Jewish (1939-1945), and architecture. 4. Irving, David John Cawdell, 1938- -Trials, litigation, etc. 5. Lipstadt, Deborah E.-Trials, litigation, etc. 6. Penguin (Firm)-Trials, litigation, etc. 7. Trials (Libel)-England-London. 8. Holocaust denial. 9. Holocaust, Jewish (1939-1945)-Historiography. I. Bordeleau, Anne, 1972- . Casts court.

D805.5.A96E95 2016 940.53’18 C2016-902107-6

First Edition

$\begin{array}{llllllllll}10 & 9 & 8 & 7 & 6 & 5 & 4 & 3 & 2 & 1\end{array}$

Printed and bound in Canada by Maracle Press 
In memory of Henryk Tauber Fuchsbrunner (1917-2000), for his invaluable 1945 testimony on the design and operation of the Auschwitz gas chambers. 
This page intentionally left blank 